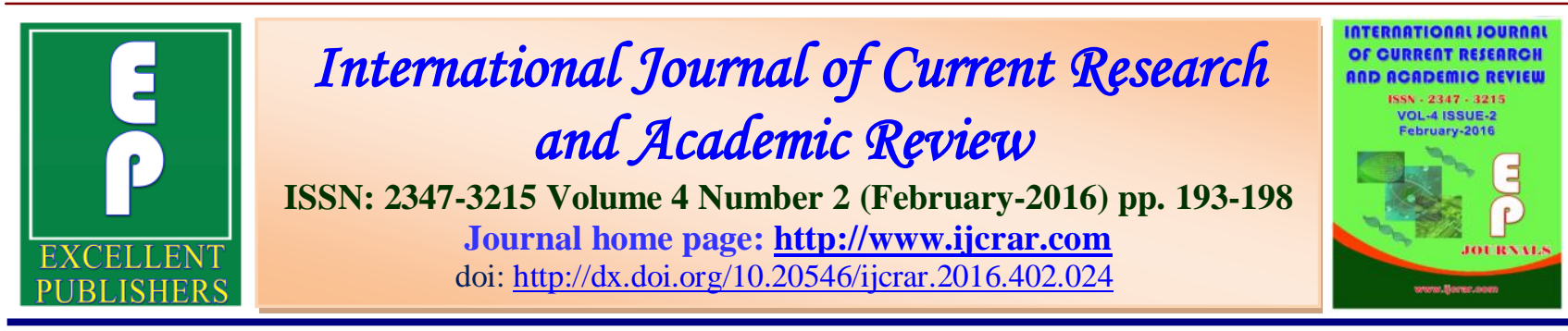

\title{
Plant Based Remedies Used by the People of Jalna District, Maharashtra State, India
}

\author{
Nandkishor K. More* and Arvind S. Dhabe
}

Department of Botany, Dr. Babasaheb Ambedkar Marathwada University, Aurangabad431004 (M. S.), India

*Corresponding author

\begin{tabular}{l|l}
\hline KEYWORDS & A B S T R A C T
\end{tabular}

Local People,

Ethnomedicinal plants,

Jalna District
Present paper deals with documentation of ethnomedicinal plants of Jalna district of Maharashtra state. This includes, information of 14 medicinal plants belonging to 12 angiosperm families used by local people and traditional practicener. The plant based treatments to cure the various diseases knows many people of Jalna district, this have important values since long time. All the given medicinal plants are arranged alphabetically with their families, followed by local names, diseases and mode of administrations in tabulated form in Table 1.

\section{Introduction}

Medicinal Plants are globally important for the human beings through its vital role to cure various ailments and diseases. Starting from civilization man has long been associated with medicinal plants. Based on methods and practices, many indigenous systems were found in India, those are found in era of Vedas. Vedic phase dates about 1200 to $800 \mathrm{BC}$. The traditional knowledge about plants has many communities in India. Traditional knowledge is said to be the wisdom developed by any people over many generations for proper utilization of their lands, natural resources and environments; it reflects in their life style, innovations and practices (S. K. Jain, 2005). Therefore documentation of such information needed.

The present work focuses on medicinal plant resources and their utility by the local people. The Jalna district has very less forest area and most of the area is under cultivation and waste land. Thus the percentage of the vegetation of the district is not considered 
for the much plant diversity. So considering this reason, most of workers might have neglected the area. Apart from this, the study of medicinal plants is restricted to few particular areas of Marathwada region. The earlier available record on medicinal plants reveals that, very few attempts have been made in the Marathwada region. A few number of workers worked on traditional medicine and ethnobotany. Thus the efforts were initiated during the present work to know the plant wealth and their utility for various purposes.

The Jalna district is a part of Marathwada region in the Maharashtra State which lies between $19^{\circ} 1^{\prime}$ and $21^{\circ} 3^{\prime}$ ' North longitude and $75^{\circ} 4^{\prime}$ to $76^{\circ} 4^{\prime}$ East longitude. It has eight Tahsil and 4 Cities and 967 villages. The total geographical area of the district is $7718 \mathrm{Sq}$. Km. which contributes $2.51 \%$ to the total state area of Maharashtra. The district has a sub-tropical climate, in which the bulk of rainfall is received from the southwest monsoon, between June to September. The average annual rainfall of the district ranges between 650 to $750 \mathrm{~mm}$. The district often experiences drought with rainfall as low as 400 to $450 \mathrm{~mm}$.

The district has moderately to gently sloping undulated topography. The Northern part of the district occupies by Ajanta and Satmala hill ranges. The $95 \%$ area of the district falls in the Godavari basin. The river Godavari flows along the Southern boundary from West to East direction. The rivers Dudhana, Gulati, Purna are the principal tributaries of the river Godavari, while river Khelna and Girja are other important tributaries of river Purna which flows through the district.

\section{Materials and Methods}

For the mentioned problem certain tools and methodology were adopted; Extensive and
Intensive field surveys were carried out in the different localities of the Jalna district from July 2012 to July 2015. Consistent field trips were arranged in every month during the course of investigation. All the necessary equipments and chemicals were carried during each trip to collect more number of plant specimens and information. Along with this each medicinal plant was photographed. Ethnomedicinal uses were recorded from the different informants by questionnaires. Meanwhile several meetings have been arranged with the medicinal practitioners, rural people and different Vaidyas. Discussion on uses and medicinal properties were focused in such meetings.

In the laboratory work, after field survey, the collected plant specimens were given successive changes by using a blotting papers or newspapers. The dried specimens were processed for preparing voucher specimens by using standard Herbarium techniques. Plants were identified with help of regional different Floras (Naik, 1979; Naik et al., 1998). The plant species were confirmed by referring BAMU herbarium. The list were prepared and arranged with respective alphabetical order followed by family, local name, diseases treated, modes of Administration are given in tabulated form. The information compared with the earlier literature and publications.

\section{Results and Discussion}

During the present study, it shows that listed 14 plants belonging to 12 families have important medicinal properties to cure various ailments. These plants are primary source of medicine to the many villagers. The plants parts like leaf juice, root, stem leaves and seeds in powder form applied on various diseases. Sometimes mixture of two or more plants used like Terminalia bellirica (Gaertn.) Roxb. and A. precatorius L.; Calatropis procera (Ait.) R. Br. and 
Enicostema axillare (Poir. ex Lam.) A. Raynal.; Dendrocalamus strictus (Roxb.) Nees. and Cuminum cyminum L; Glycyrrhiza glabra L., Trachyspermum ammi (L.) Sprague. and Terminalia bellirica (Gaertn.) Roxb. This application of sound knowledge about plants knows elder person in many parts of Jalna district. The methods of treatments given by traditional practicener, Vaidyas are very cheap and have no side effects. In the observation, plant like Abrus precatorius L. useful on stomach problems of children; has very easy treatments. The details of all fourteen plants are given in the Table 1.

Table.1 Showing Plants Use to Treat Health Problems and Mode of Administration

\begin{tabular}{|c|c|c|c|c|}
\hline $\begin{array}{l}\text { Sr. } \\
\text { No. }\end{array}$ & $\begin{array}{l}\text { Botanical Name \& } \\
\text { Family }\end{array}$ & $\begin{array}{l}\text { Local } \\
\text { Name }\end{array}$ & $\begin{array}{l}\text { Disease/ } \\
\text { Health } \\
\text { Problems }\end{array}$ & Modes of Administration \\
\hline 1 & $\begin{array}{l}\text { Abrus precatorius } \mathrm{L} \text {. } \\
\text { (Papilionaceae) }\end{array}$ & $\begin{array}{l}\text { Pandhari } \\
\text { gunj }\end{array}$ & $\begin{array}{l}\text { Cold, fever } \\
\text { and stomach } \\
\text { problems }\end{array}$ & $\begin{array}{l}\text { Fresh leaves of A. precatorius crushed with water and } 3-5 \mathrm{ml} \\
\text { leaves extract orally given to children for } 2 \text { days. } \\
\text { Crushed the fresh leaves of A. precatorius and make small pills } \\
\text { then mix it with Terminalia bellirica or yela fruit powder. The } \\
\text { pills are given orally to the same children } 2 \text { times after } 30 \\
\text { minutes of interval. }\end{array}$ \\
\hline 2 & $\begin{array}{l}\text { Calatropis procera } \\
\text { (Ait.) R. Br. } \\
\text { (Asclepiadaceae) }\end{array}$ & $\begin{array}{l}\text { Rui, } \\
\text { Ruchaki }\end{array}$ & Typhoid & $\begin{array}{l}\text { A dried flower powder of } C \text {. procera, Kaval Kutki powder and } \\
\text { dried powder of Enicostema axillare mix in the proportion } 25 \% \text {, } \\
50 \%, 25 \% \text {; half teaspoon taken orally with honey } 3 \text { times for } \\
\text { two days to cure typhoid. }\end{array}$ \\
\hline 3 & $\begin{array}{l}\text { Commiphora wightii } \\
\text { (Arn.) Bhandari. } \\
\text { (Burseraceae) }\end{array}$ & Gugul & $\begin{array}{l}\text { Shingles or } \\
\text { Herpes Zoster }\end{array}$ & $\begin{array}{l}\text { Add Gugul gums and Geru powder in } 100 \mathrm{ml} \text { water, mix it well } \\
\text { and apply on skin were Shingles occurred on the skin; a pest of } \\
\text { Boswellia serrata leaves applied to cold skin. }\end{array}$ \\
\hline 4 & $\begin{array}{l}\text { Dendrocalamus } \\
\text { strictus (Roxb.) Nees. } \\
\text { (Poaceae) }\end{array}$ & Velu & Leucorrhoea & $\begin{array}{l}\text { A complete leaves of D. strictus and powder of Cuminum } \\
\text { cyminum L. (Marathi: Jire), pest it and mix with one cup of } \\
\text { water; the mixture is given orally to ladies to treat Leucorrhoea } \\
\text { in the early morning. }\end{array}$ \\
\hline 5 & $\begin{array}{l}\text { Ipomoea obscura (L.) } \\
\text { Ker. Gawl. } \\
\text { (Convolvulaceae) }\end{array}$ & & Baldness & $\begin{array}{l}\text { Prepare a homogenized mixture of } 50 \text { grams leaves of I. obscura } \\
+25 \text { grams large size salt }+200 \mathrm{ml} \text { water; Apply it for the } \\
\text { baldness in the } 2 \text { hours intervals for one day only. The best time } \\
10 \text { am to } 5 \text { pm. Precautions: don't wash the head for two days; } \\
\text { don't use any oil, shampoo, and soap to wash the head. }\end{array}$ \\
\hline 6 & $\begin{array}{l}\text { Musa paradisiaca } \mathrm{L} . \\
\text { (Musaceae) }\end{array}$ & Keli & Piles & $\begin{array}{l}\text { Mix one ripe fruit Musa paradisiaca with } 3 \text { camphor cake and } \\
\text { eat the mixture for } 3 \text { days to cure piles when blooded. }\end{array}$ \\
\hline 7 & $\begin{array}{l}\text { Oscimum basilicum } \\
\mathrm{L} .\end{array}$ & Ran tulas & Eye problems & $\begin{array}{l}\text { Drop 5-6 seeds of } O \text {. basilicum in the eye and close for few } \\
\text { minutes to remove the external agent in the eye. }\end{array}$ \\
\hline
\end{tabular}


Int.J.Curr.Res.Aca.Rev.2016; 4(2): 193-198

\begin{tabular}{|c|c|c|c|c|}
\hline & (Lamiaceae) & & & \\
\hline 8 & $\begin{array}{l}\text { Phyllanthus } \\
\text { reticulatus Poir. } \\
\text { (Euphorbiaceae) }\end{array}$ & $\begin{array}{l}\text { Kala } \\
\text { Mohan }\end{array}$ & Piles & $\begin{array}{l}\text { Total } 10-12 \text { fresh leaves of } P \text {. reticulatus crush and given orally } \\
\text { to patient in morning at empty stomach for } 21 \text { days. } \\
\text { About } 50 \text { grams of } P \text {. reticulatus leaves soaked in copper metal } \\
\text { pots or a rounded water pot and keep it over night. Remove the } \\
\text { leaves and filter the water with the help of tea strainer; water is } \\
\text { given to same patient for drinking in morning time. }\end{array}$ \\
\hline 9 & $\begin{array}{l}\text { Terminalia arjuna } \\
\text { (Roxb.) Wt. \& Arn. } \\
\text { (Combretaceae) }\end{array}$ & $\begin{array}{l}\text { Arjun } \\
\text { Shadada }\end{array}$ & $\begin{array}{l}\text { Wound } \\
\text { Healing }\end{array}$ & $\begin{array}{l}\text { Cover bark powder of Arjun Shadada all over part of wound and } \\
\text { tie with the help of Cloth or bandage. Repeat it for 2-3 days. }\end{array}$ \\
\hline 10 & $\begin{array}{l}\text { Pongamia pinnata } \\
\text { (L.) Pierre. } \\
\text { (Papilionaceae) }\end{array}$ & Karanj & Pain Joints & Seed oil Pongamia pinnata is useful on pain joints. \\
\hline 11 & $\begin{array}{l}\text { Madhuca longifolia } \\
\text { (Koen.) Macbr. var. } \\
\text { latifolia (Roxb.) A. } \\
\text { Chevalier. } \\
\text { (Sapotaceae) }\end{array}$ & Moha & Pain Joints & Seed oil of Madhuca longifolia is useful on pain joints. \\
\hline 12 & $\begin{array}{l}\text { Bryophyllum } \\
\text { pinnatum (Lam.) } \\
\text { Oken. } \\
\text { (Crassulaceae) } \\
\end{array}$ & Pakhanbel & Leucorrhoea & $\begin{array}{l}\text { Two teaspoon of Pakhanbel powder in one glass on water is } \\
\text { given orally ladies patient on Leucorrhoea. The dosage is given } \\
\text { to 3-7 days once in morning and evening. }\end{array}$ \\
\hline 13 & $\begin{array}{l}\text { Pergularia daemia } \\
\text { (Forssk.) Choiv. } \\
\text { (Asclepiadaceae) }\end{array}$ & Utaran & $\begin{array}{l}\text { Finger } \\
\text { Infection }\end{array}$ & $\begin{array}{l}\text { A pest of Pergularia leaves and sugar is tight to the finger on } \\
\text { finger infection. }\end{array}$ \\
\hline 14 & $\begin{array}{l}\text { Trachyspermum } \\
\text { ammi (L.) Sprague. } \\
\text { ( Apiaceae) }\end{array}$ & Owa & $\begin{array}{l}\text { Acidity, } \\
\text { Indigestion, } \\
\text { Cough }\end{array}$ & $\begin{array}{l}\text { Ingredients of Jestmadh Churna: Prepared from equal } \\
\text { proportion of Jestmadh root (Glycyrrhiza glabra L.), } \\
\text { Trachyspermum ammi (Marathi: Owa), Black salt, Bark of } T \text {. } \\
\text { bellirica. } \\
\text { Two teaspoon churna in one glass of water or milk is useful on } \\
\text { acidity, Indigestion, Cough. The dosage given before and after } \\
\text { the lunch. }\end{array}$ \\
\hline
\end{tabular}

Note- Kaval Kutki powder *; Geru powder * available in the market at Ayurvedic Shoppe 
Fig.1 Subhash Rathod at Pangari Gosavi

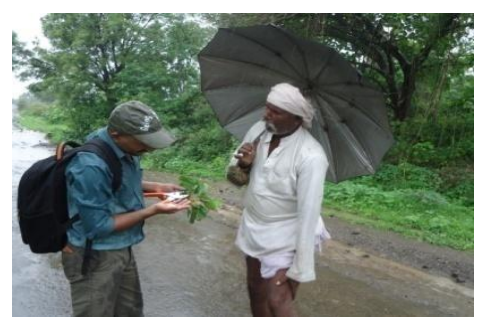

Fig.2 Chagan Shahane at Neemgaon

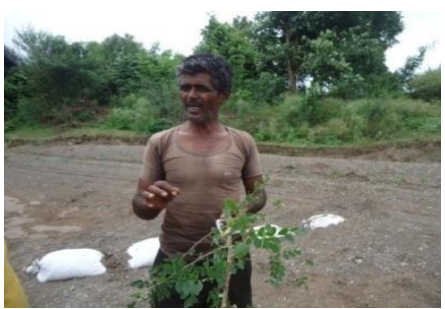

Fig.3 Mule Mama at Vatur Phata

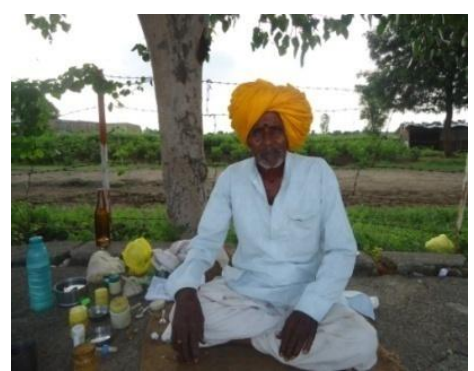

\section{Conclusion}

In the study area it was observed than local people facing a many health problems; now they are engage to use plant based remedies given by the traditional practicener. The medicinal plants given in the result were useful common health problems of the people. The health problems viz. Eye problems, Typhoid, Shingles or Herpes Zoster, Leucorrhoea, Baldness, Piles, Cold, fever, Piles, Wound Healing, Pain Joints, Leucorrhoea, Finger Infection, Acidity, Indigestion, and Cough are commonly found in the study area. Thus, the documentation of such observation needed for human kind. Because these traditional knowledge were limited for the particular generation. Given plants need to evaluated further in the research to know its potential as drugs and medicines.

\section{Acknowledgement}

Authors are thankful Head of Department, Dr. Babasaheb Ambedkar Marathwada University, Aurangabad for providing necessary facilities. We are also thankful to all informants for sharing the valuable information and UGC, for financial support during the works.

\section{References}

Almeida A. P., 2003. Flora of Maharashtra, Vol. I-III, Blatter Herbarium, St. Xavier's College, Mumbai. 
Anonymous 2013. District Social and Economical Analysis, District Jalna, Directorate of Economics and Statistics, Govt. of Maharashtra, Mumbai.

Deshmukh R. R., 2010. Ethnobotanical Exploration in Marathwada, Ph. D. Thesis, Dr. B. A. M. University, Aurangabad.

Jain S. K., 2005. Dynamism of Traditional Knowledge, Indian Journal of Traditional Knowledge, Vol. 4(2), April 2005, pp. 115-117.

Naik V. N., 1979. The Flora of Osmanabad, Venus Publishers, Aurangabad.

Naik V. N., 1998. Flora of Marathwada Vol. I \&II, Amrut Prakashan, Aurangabad.

Naser Rafiuddin 2003. Forest wealth and Utility of Plants in Aurangabad district, Ph. D. Thesis, Dr. B. A. M. University, Aurangabad.

Patil M. V. \& Patil D. A., 2006. Ethnobotany of Nashik District,
Maharashtra, House, Delhi.

Sardesai M. M. \& Yadav S. R., 2002. Flora of Kolhapur District, Shivaji University, Kolhapur.

Sukh Dev 2012. Prime Ayurvedic Plant Drugs: A Modern Scientific Appraisal, Ane Book Pvt. Ltd., New Delhi.

Survase S. A., Chavan D. P. and Kulkarni A. U., 2013. Tree Diversity of Jalna District, Marathwada and Their Utilization, Proc. of National Conference on CMPTU, in Adarsh College Hingoli on $9^{\text {th }} \& 10^{\text {th }}$ December 2013.

Survase S. A. \& Dhabe A. S., 2013. "BAMU" Herbarium and Herbarium technique, Bioinfolet, 10(4A): pp. 1177-1180.

\section{How to cite this article:}

Nandkishor K. More and Arvind S. Dhabe. 2016. Plant Based Remedies Used by the People of Jalna District, Maharashtra State, India. Int.J.Curr.Res.Aca.Rev. 4(2): 193-198.

doi: http://dx.doi.org/10.20546/ijcrar.2016.402.024 